\title{
In Their Words: Critically Analyzing the Admission of "Me Too" Testimony in Kansas
}

\author{
TJ Blake*
}

\section{INTRODUCTION}

Three decades ago, the Supreme Court held in Meritor Savings Bank $v$. Vinson that workplace harassment was an actionable form of discrimination prohibited by Title VII of the Civil Rights Act of 1964 . $^{1}$ Vinson offered hope that workplace discrimination would one day be eradicated. ${ }^{2}$ However, taking one look across newspapers, televisions, social media, and magazines will tell you that we still have a long way to go. ${ }^{3}$ Charges of employment discrimination have been at the forefront of media over the last year. ${ }^{4}$ On October 15, 2017, following a flood of over fifty accusations against Hollywood producer Harvey Weinstein, the social media platform Twitter began to buzz after actress Alyssa Milano tweeted, "If you've been sexually harassed or assaulted write 'me too' as a reply to this tweet." In response, women across the platform began to

* Tyler J. Blake, J.D. candidate 2020, University of Kansas School of Law; B.A. Political Science, B.S.J. Strategic Communications (2017), University of Kansas. I would like to extend my gratitude to Professor Kyle Velte and the Kansas Law Review for the insightful comments and suggestions throughout the editing process. I would also like to thank my family, friends, and former teachers for their continued love, support, and encouragement. Without them, this would not be possible.

1. Meritor Sav. Bank, FSB v. Vinson, 477 U.S. 57, 66-67 (1986).

2. See Al Kamen, Court Rules Firms May Be Liable for Sexual Harassment, WASH. Post (June 20, 1986), https://www.washingtonpost.com/archive/politics/1986/06/20/court-rules-firms-may-beliable-for-sexual-harassment/83ecaae2-74c7-4bea-8d9e-12b7e0023ef7/?utm_term=.7137f85f6b67 [https://perma.cc/ZD7Z-U2CU] (illustrating hopeful remarks from organizations that fight workplace sexual harassment following the Vinson decision, including the U.S. Chamber of Commerce General Counsel and the National Organization for Women).

3. See Alix Langone, \#MeToo and Time's Up Founders Explain the Difference Between the 2 Movements - and How They're Alike, TIME (Mar. 8, 2018), http://time.com/5189945/whats-thedifference-between-the-metoo-and-times-up-movements/ [https://perma.cc/WC27-NYYC] (identifying key points in various recent sexual harassment movements).

4. Fiza Pirani, \#MeToo: A Timeline of 2018's Sexual Harassment Scandals, Atlanta J. \& CONST. (May 25, 2018), https://www.ajc.com/news/national/metoo-timeline-2018-sexualharassment-scandals/Lv8ftAS6o0EMSdmqfo2R1L/ [https://perma.cc/8M9D-CTTZ] (outlining the multitude of media-worthy events).

5. Alyssa Milano (@Alyssa_Milano), TwiTter (Oct. 15, 2017, 1:21 PM), https://twitter.com/Alyssa_Milano/status/919659438700670976/photo/1?ref_src=twsrc\%5Etfw\&ref 
share their stories of similar experiences of inappropriate - and often illegal-behavior. Socially powerful women, including Hollywood stars and Olympic gold medalists, shared their stories and identified prominent men who had committed these acts. ${ }^{6}$ The \#MeToo movement ${ }^{7}$ sparked an immediate reaction to the pervasive presence - and in many cases tolerance - of sexual harassment and discrimination in the professional, political, and legal environments. ${ }^{8}$

Roughly half of women in the workforce say they have personally experienced unwanted sexual advances at work. ${ }^{9}$ An even larger percentage identify sex discrimination and harassment as a serious issue. ${ }^{10}$ Despite this fact, statistics show that nearly $75 \%$ of women who experience workplace harassment and discrimination do not report it. ${ }^{11}$ As the number of allegations continue to surface, it has become clear that a common factor keeps these individuals from speaking up-fear. ${ }^{12}$ This is

_url=https\%3A\%2F\%2Fwww.nytimes.com\%2F2017\%2F10\%2F16\%2Ftechnology\%2Fmetootwitter-facebook.html [https://perma.cc/28UA-HC63]. See, e.g., Heidi Stevens, \#MeToo Campaign Proves Scope of Sexual Harassment, Flaw in Mayim Bialik's Op-ed, CHI. TRIB. (Oct. 16, 2017), $\mathrm{http}: / /$ www.chicagotribune.com/lifestyles/stevens/ct-life-stevens-monday-me-too-mayim-bialik1016-story.html [https://perma.cc/6GLS-HW8D]; Harvey Weinstein Scandal: Who Has Accused Him of What?, BBC (Jan. 10, 2019), https://www.bbc.com/news/entertainment-arts-41580010 [https://perma.cc/PW8B-NTDU].

6. Richard Winton et al., McKayla Maroney Accuses USOC and USA Gymnastics of Covering Up Sexual Abuse With Secret Settlement, L.A. TIMES (Dec. 21, 2017), https://www.latimes.com/ local/lanow/la-me-maroney-gynnastics-settlement-20171220-story.html [https://perma.cc/4RPHQUSK]; Helaine Olen, Sexual Harassment Does Not Occur in a Vacuum, THE NATION (Dec. 4, 2017), https://www.thenation.com/article/sexual-harassment-does-not-occur-in-a-vacuum/ [https://perma.cc /ELY4-ZU75].

7. This Note will refer to the \#MeToo movement and "me too" evidence. The \#MeToo movement involves the social political changes involving sexual harassment and discrimination that was started by outcry from prominent women. "Me too" evidence is the term used to describe testimony from similarly situated employees in suits involving harassment and discrimination.

8. Mary Pflum, A Year Ago, Alyssa Milano Started a Conversation About \#MeToo. These Women Replied, NBC News (Oct. 15, 2018), https://www.nbcnews.com/news/us-news/year-agoalyssa-milano-started-conversation-about-metoo-these-women-n920246 [https://perma.cc/PEV9NBD6] (characterizing the aftermath of Milano's "Me Too" tweet and the subsequent \#MeToo movement).

9. See, e.g., Caitlin Gibson \& Emily Guskin, A Majority of Americans Now Say that Sexual Harassment is a "Serious Problem", WASH. POST (Oct. 17, 2017), https://www.washingtonpost.com /lifestyle/style/a-majority-of-americans-now-say-that-sexual-harassment-is-a-serious-problem/2017/ 10/16/707e6b74-b290-11e7-9e58-e6288544af98_story.html?utm_term=.dd3eceaf19a8

[https://perma.cc/5LNM-4ESC]; Ellen Brickman \& Chad Lackey, Perceptions of Discrimination and Harassment in a \#MeToo World: Implications for Litigating Employment Cases, DOAR RES. CTR. 8 (2018), https://www.doar.com/wp-content/uploads/2018/08/Perceptions-Of-Discrimination-AndHarassment-In-A-MeToo-World.pdf [https://perma.cc/Q7D4-N63E].

10. See Gibson \& Guskin, supra note 9.

11. Chai R. Feldblum \& Victoria A. Lipnic, Report of the Co-Chairs of the Select Task Force on the Study of Harassment in the Workplace, EEOC (2016), https://www.eeoc.gov/eeoc/ task_force/harassment/report.cfm [https://perma.cc/EEP9-QDZD].

12. See Brickman \& Lackey, supra note 9, at 10. 
especially true for people with multiple (commonly known as "intersecting" ") minority identities who fear that breaking their silence could mean loss of employment, physical violence, or social ostracization. ${ }^{14}$ People who possess these multiple intersecting identities experience a compounded pressure to keep quiet in fear of retaliatory measures. ${ }^{15}$ The Equal Employment Opportunity Commission (EEOC) has identified the significance of this power imbalance between employers and employees. This "quid pro quo" harassment, as coined by the EEOC, forces women to endure harassment or discrimination simply out of fear of termination. ${ }^{16}$ Sexual harassment is not limited to unwanted sexualized behavior, but also includes the unchecked power imbalances present in workplace dynamics. ${ }^{17}$ This power imbalance permeates Hollywood, universities, law firms, and factories - pervading both the highest and lowest economic positions in our society. ${ }^{18}$ The creation of the \#MeToo movement gave these victims an outlet to acknowledge collective patterns of inappropriate behavior without forcing a victim to shoulder the risk in isolation.

Now, almost three years later, the \#MeToo movement is still bringing

13. Intersectionality can be described as the predicament of "double discrimination" people experience when they possess multiple marginalizing characteristics such as race, class, gender, or sexuality. Intersectionality is sometimes experienced as the compounded experience of both characteristics, while other times, the intersection of two marginalized characteristics create a wholly new category of experience that is unique to that particular intersection. See generally Julia S. Seng, Marginalized Identities, Discrimination Burden, and Mental Health: Empirical exploration of an interpersonal-level approach to modeling intersectionality, 75 SOCIAL SCIENCE \& MEDICINE 2437 (2012). See, e.g., D. Wendy Greene, Black Women Can't Have Blonde Hair in the Workplace, 14 J. GENDER, RACE \& JUST. 405 (2011) (describing the unique experience of being a Black woman in the workplace as well as the historical and social implications of race and gender).

14. Stephanie Zacharek, Eliana Dockterman \& Haley Sweetland Edwards, TIME Person of the Year 2017: The Silence Breakers, TIME (last visited Apr. 1, 2019), http://time.com/time-person-ofthe-year-2017-silence-breakers/ [https://perma.cc/32WM-NVUG]; Serena Mayeri, Intersectionality and Title VII: A Brief (Pre-)History, 95 B.U. L. ReV. 713, 727-32 (2015).

15. Dulini Fernando \& Ajnesh Prasad, How Managers, Coworkers, and HR Pressure Women to Stay Silent About Harassment, HARV. BuS. Rev. (July 13, 2018), https://hbr.org/2018/07/howmanagers-coworkers-and-hr-pressure-women-to-stay-silent-about-harassment [https://perma.cc/ 8L9T-V8KU]; Rachel Kahn Best, Linda Hamilton Krieger, Lauren B. Edelman \& Scott R. Eliason, Multiple Disadvantages: An Empirical Test of Intersectionality Theory in EEO Litigation, 45 LAW \& SOC'Y REV. 991, 994, 1018-19 (2011).

16. See An Open Secret: Sexual Harassment at Work, Economist (Oct. 21, 2017), https://www.economist.com/international/2017/10/21/sexual-harassment-at-work [https://perma.cc 13785-CTZ3].

17. Rachel Arnow-Richman, Of Power and Process: Handling Harassers in an At-Will World, 128 YALE L.J.F. 85, 87 (2018).

18. Anne-Marie Slaughter, Sexual Harassment is Rooted in Power Imbalances, Fin. Times (Oct. 26, 2017), https://www.ft.com/content/1d624ee0-b8af-11e7-bff8-f9946607a6ba [https://perma.cc /ZF8V-24ZP] (detailing how gender inequality and workplace power distribution prevents the individual woman from speaking about her own sexual harassment). 
victims of prominent figures into the limelight. ${ }^{19}$ In the legal realm, Supreme Court Justice Brett Kavanaugh faced many allegations of sexual assaults during his nomination and confirmation process. ${ }^{20}$ After Dr. Christine Blasey Ford accused Kavanaugh of sexual assault, other women came forward with similar experiences of Kavanaugh's alleged inappropriate conduct. ${ }^{21}$ The Senate Judiciary Committee held a hearing to determine the credibility of the women's accusations against him. ${ }^{22}$ In light of the allegations, the American public became intensely divisive. Some argued that the Committee should believe Dr. Ford's allegations and congressional members should recognize the inherent risk of coming forward to address an instance of sexual assault. ${ }^{23}$ Others argued the accusations lacked direct evidence and that the hearing was an attempt to smear the character of a potential Supreme Court Justice. ${ }^{24}$ While not governed by the Kansas evidentiary rules, Justice Kavanaugh's nomination hearing contained many of the same arguments debated in the context of testimonial evidence offered to prove misconduct. Under

19. David W. Garland, What does 2019 Have in Store for \#MeToo?, HR Dive (Dec. 5, 2018), https://www.hrdive.com/news/what-does-2019-have-in-store-for-metoo/543464/ [https://perma.cc/ M5U7-GWTG] (documenting the increase in sexual harassment claims brought to the EEOC in 2018).

20. Seung Min Kim, Ann E. Marimow, Mike DeBonis \& Elise Viebeck, Kavanaugh Hearing: Supreme Court Nominee Insists on His Innocence, Calls Process 'National Disgrace', WASH. POST (Sept. 27, 2018), https://www.washingtonpost.com/politics/kavanaugh-hearing-christine-blasey-fordto-give-senate-testimony-about-sexual-assault-allegation/2018/09/27/fc216170-c1c3-11e8-b338a3289f6cb742_story.html?utm_term=.91af626e313b [https://perma.cc/6PZ2-XXWZ] (summarizing the events of the Kavanagh hearing).

21. Ronan Farrow \& Jane Mayer, Senate Democrats Investigate a New Allegation of Sexual Misconduct, From Brett Kavanaugh's College Years, NEW YORKER (Sept. 23, 2018), https://www.newyorker.com/news/news-desk/senate-democrats-investigate-a-new-allegation-ofsexual-misconduct-from-the-supreme-court-nominee-brett-kavanaughs-college-years-deborahramirez [https://perma.cc/QZ6U-WVHQ] (providing an example of another credible allegation against Justice Kavanaugh).

22. Seung Min Kim et al., supra note 20.

23. See, e.g., Domenico Montanaro, Poll: More Believe Ford Than Kavanaugh, A Cultural Shift from 1991, NPR POLITICS (Oct. 3, 2018), https://www.npr.org/2018/10/03/654054108/poll-morebelieve-ford-than-kavanaugh-a-cultural-shift-from-1991 [https://perma.cc/2RT3-YXBH]; Nicole Brodeur, Why Should We Believe Christine Blasey Ford? It's In the Details, SEATtLE Times (Sept. 27, 2018) https://www.seattletimes.com/seattle-news/why-should-we-believe-christine-blasey-fordits-in-the-details/ [https://perma.cc/3PYU-YGPU] (documenting evidence of support for Dr. Blasey Ford and her testimony).

24. See, e.g., Allie Malloy, Kate Sullivan \& Jeff Zeleny, Trump Mocks Christine Blasey Ford's Testimony, Tells People to 'Think of Your Son', CNN POLITICS (Oct. 3, 2018), https://www.cnn.com/ 2018/10/02/politics/trump-mocks-christine-blasey-ford-kavanaugh-supreme-court/index.html [https://perma.cc/8MRY-T5SS]; President Donald J. Trump (@realDonaldTrump), TwiTTER (Sept. 27, 2018, 5:46 PM), https://twitter.com/realDonaldTrump/status/1045444544068812800?ref_src=tw src\%5Etfw\%7Ctwcamp\%5Etweetembed\%7Ctwterm\%5E1045444544068812800\&ref_url=https\%3 A\%2F\%2Fwww.haaretz.com\%2Fus-news\%2Fa-guide-to-the-ford-kavanaugh-hearing-1.6512344 [https://perma.cc/LYF7-JQYH] (arguing Kavanaugh's testimony was "powerful, honest, and riveting" and the hearing was "a total sham"). 
K.S.A. $\S 60-455$, testimony by other employees of discrimination or harassment not experienced by the plaintiff may be kept from the record for a number of reasons, even if the evidence may seem to provide logical validity to the plaintiff's claim.

This Note advocates for changes in the test used to determine what evidence is admitted under the Kansas Rules of Evidence under K.S.A. $\S$ 60-455. As the \#MeToo movement continues to expose harassment and discrimination, the public will continue to pressure courts to acknowledge the systematic challenges faced by women in the employment context. Employment discrimination cases frequently hinge on the admission of circumstantial evidence to compensate for the rare presence of direct evidence. When balancing the admission of "me too" evidence in a case of single-act employment discrimination, Kansas courts should consistently weigh the maximum potential probative impact against the minimum potential for prejudice and only exclude evidence when the prejudicial value substantially outweighs the probative value. This Note will provide background for this argument by distinguishing between the \#MeToo movement and "me too" testimony, articulating the rules currently used to determine the admissibility of evidence, and explain the function of the minimum-maximum ("min-max") test. ${ }^{25}$

\section{BACKGROUND}

While the \#MeToo movement has made a dramatic effect on society in the last few years, the term itself is not new to the legal claims of sexual harassment. In cases of employment harassment and discrimination, plaintiffs often lack significant direct evidence to prove their civil claims. ${ }^{26}$ Because of this, circumstantial evidence has become increasingly important as employers become more aware of the risks and costs of explicit discrimination. ${ }^{27}$ In our modern economy, employers refrain from outwardly relying on identity-based differentiation and they will not admit to discriminatory intent. ${ }^{28}$ Therefore, the presence of direct

25. This Note will refer to the test that maximizes the potential probative value and minimizes the potential prejudicial value as the min-max test.

26. See An Open Secret, supra note 16 (stating that in complaints of sexual harassment in the workplace, there is very rarely any kind of supporting evidence, hinging on a he said, she said discussion).

27. See Sherie L. Coons, Proving Disparate Treatment After St. Mary's Honor Center v. Hicks: Is Anything Left of McDonnell Douglas, 19 J. CORP. L. 379, 381-82 (1994) (articulating the unique difficulties faced in employment discrimination cases).

28. Suzanne B. Goldberg, Discrimination by Comparison, 120 YALE L.J. 728, 731-32 (2011) (noting the market and social changes that have prompted the shift away from identity-based 
evidence is becoming more scarce over time. The term "me too" evidence is used to describe the testimony of employees who experienced the same or similar experiences to the plaintiff, but did not necessarily file independent claims of their own. ${ }^{29}$ In many cases, a supervisor may have discriminated against or harassed multiple employees. The defendant will attempt to keep this testimonial evidence out and will likely file a motion in limine to exclude it. ${ }^{30}$ Not unlike the divided reaction to Kavanaugh's appointment, courts have been divided in their use of "me too" evidence. ${ }^{31}$ Some courts recognize the significant probative value that is provided by additional testimony ${ }^{32}$ while others believe including evidence beyond the isolated occurrence unfairly prejudices a jury against a defendant. ${ }^{33}$

\section{A. Weighing of "me too" evidence in federal law}

Because the admission of "me too" evidence in discrimination cases is so contentious, it is important to understand how the court determines whether such testimony should be included at trial. At the federal level, courts operate using the Federal Rules of Evidence. At the state level, each state has developed its own rules of evidence through statute-some closer to the federal rules than others. The Federal Rules of Evidence are not always followed by individual states, but most will, at the very least, take the federal rules as strong persuasive authority. ${ }^{34}$ Therefore, even when evaluating a state's evidence procedure, it is important to analyze how the federal courts have proceeded.

In the context of "me too" evidence, the starting point for evidentiary analysis begins with Federal Rule of Evidence (Rule 401) which

differentiation).

29. See David L. Gregory, Sprint/United Management Company v. Mendelsohn and Case-byCase Adjudication of "Me Too" Evidence of Discrimination, 102 N.W. U. L. REV. COLLOQUY 382, 385 (2008).

30. See, e.g., Mendelsohn v. Sprint/United Mgmt. Co., 466 F.3d 1223, 1225 (10th Cir. 2006), vacated, 552 U.S. 379 (2008); Cox v. Kan. City Chiefs Football Club, Inc., 473 S.W.3d 107, 113-14 (Mo. 2015).

31. Emily D. Wilson, Sprint/United Management Co. v. Mendelsohn: Tenth Circuit Employment Law Remains in "Me Too" Limbo, 63 OKLA. L. REV. 167, 172 (2010).

32. See, e.g., Hawkins v. Hennepin Tech. Ctr., 900 F.2d 153, 156 (8th Cir. 1990); Spulak v. K Mart Corp., 894 F.2d 1150, 1156 (10th Cir. 1990).

33. See, e.g., Wyvill v. United Cos. Life Ins. Co., 212 F.3d 296, 302-04 (5th Cir. 2000); Haskell v. Kaman Corp., 743 F.2d 113, 121 (2d Cir. 1984).

34. Burton S. DeWitt, The Application and Construction of Rules of Admissibility in the Federal Rules of Evidence in Cases Where State Law Provides the Rule of Decision, 34 REV. LiTIG. 283, 286 (2015) (outlining the historical development of the Federal Rules of Evidence); See generally, Kenneth Graham, State Adaptation of the Federal Rules: The Pros and Cons, 43 OKLA. L. REV. 293 (1990). 
determines the general test for relevance. ${ }^{35}$ This rule creates a low threshold for relevance. Courts frequently interpret the phrase "any tendency to make a fact more or less probable" to mean that any evidence that provides a slight impact on the assessment of the probability of the claim is relevant. ${ }^{36}$ Most "me too" evidence is used by plaintiffs to help construct cases of discrimination. ${ }^{37}$ While testimony regarding other employer misconduct cannot fully prove a plaintiff's claim, circumstantial evidence, such as previous harassment by the employer, seems to make it more probable. Thus, most "me too" evidence likely meets the baseline test of relevance. ${ }^{38}$

Additionally, "me too" evidence is frequently presented in the form of testimony regarding conduct, behavior, or character of employers. The Federal Rules of Evidence provide specific limitations on character evidence in Rule 404. Because of this, Rule 404(b) should be examined:

(1) Prohibited Uses. Evidence of a crime, wrong, or other act is not admissible to prove a person's character in order to show that on a particular occasion the person acted in accordance with the character.

(2) Permitted Uses; Notice in a Criminal Case. This evidence may be admissible for another purpose, such as proving motive, opportunity, intent, preparation, plan, knowledge, identity, absence of mistake, or lack of accident. ... 39

The Federal Rules of Evidence generally prohibits character evidence, but Rule 404(b)(2) provides clear exceptions to the broad exclusion. ${ }^{40}$ Motive, intent, and state of mind are all accepted purposes for admission and should be considered in the context of testimony of other discriminatory conduct by employers. ${ }^{41}$ Often, there are no issues raised at this stage.

Finally, a court reviews the evidence in a Rule 403 balancing test. This rule favors admissibility and allows for factors such as "unfair prejudice, confusing the issues, misleading the jury, undue delay, wasting

\footnotetext{
35. FED. R. EVID. 401.

36. Jack B. Weinstein \& Margaret A. Berger, Weinstein's Federal Evidence, § 401.04[2][c] (2d ed. 1997).

37. See Wilson, supra note 31 , at 170.

38. Nicholas C. Soltman, What About "Me (Too)"? The Case for Admitting Evidence of Discrimination Against Nonparties, 76 U. CHI. L. REV. 1875, 1900 (2009).

39. FED. R. EVID. 404(b).

40. Charles H. Rose III, Caging the Beast: Formulating Effective Evidentiary Rules to Deal with Sexual Offenders, 34 AM. J. CRIM. L. 1, 13 (2006).

41. Lisa Marshall, The Character of Discrimination Law: The Incompatibility of Rule 404 and Employment Discrimination Suits, 114 YALE L.J. 1063, 1071, 1073 (2005).
} 
time, or needlessly presenting cumulative evidence" to be weighed against the probative value of the evidence. ${ }^{42}$ When determining whether evidence should be admitted under Rule 403, a court may exclude relevant evidence only when these factors substantially outweigh the probative value of the evidence. Executing a Rule 403 balancing test is more contentious than it might appear. Courts have weighed the evidence using a number of factors over time to determine the probative and prejudicial impact of witness testimony.

\section{Sprint/United Mgmt. Co. v. Mendelsohn}

While it might seem reasonable that the Supreme Court would recognize this contentious issue and address the discrepancy, Sprint/United Mgmt. Co. v. Mendelsohn sent a clear message that the Supreme Court was leaving this debate to the lower courts. This federal case arose from a purported violation of the Age Discrimination in Employment Act (ADEA), 29 U.S.C. $\$ \S 621-634 .{ }^{43}$ Mendelsohn wanted to admit the "me too" testimony of five other employees who believed they were subject to discrimination and harassment based on their ages. ${ }^{44}$ Mendelsohn's case, like most employment discrimination cases, depended heavily on this evidence.

The United States District Court for the District of Kansas excluded the "me too" testimonial evidence of the former employees, alleging discrimination by supervisors who had no role in the employment decision Mendelsohn challenged. ${ }^{45}$ The Court reasoned that these employees were not similarly situated because they did not have the same supervisor as Mendelsohn. ${ }^{46}$ Thus, the testimonial evidence was excluded. ${ }^{47}$

The United States Court of Appeals for the Tenth Circuit interpreted this exclusion as an inappropriately applied per se rule. ${ }^{48}$ The Court held that the per se exclusion of testimony was not proper based on an individual factor and then proceeded to conduct its own balancing test of

\footnotetext{
42. FED. R. EVID. 403; Amy S. Thomas, Utah Rule of Evidence 403 and Gruesome Photographs: Is a Picture Worth Anything in Utah?, 1996 UTAH L. Rev. 1131, 1133 (1996).

43. Mendelsohn v. Sprint/United Mgmt. Co., No. 03-2429-KHV, 2004 U.S. Dist. LEXIS 30629 (D. Kan. Nov. 29, 2004).

44. See Wilson, supra note 31, at 181.

45. Id. at 182 .

46. Mendelsohn v. Sprint/United Mgmt. Co., 466 F.3d 1223, 1225 (10th Cir. 2006), vacated, 552 U.S. 379 (2008).

47. Id.

48. Id. at 1226
} 
the testimony. ${ }^{49}$ The Court determined the testimony should be admitted under Rule 403, reversed the district court's order denying Mendelsohn's motion for a new trial, and remanded the case to the district court for further proceedings consistent with its opinion. ${ }^{50}$

Upon appeal to the Supreme Court, Mendelsohn's outcome became a highly anticipated answer to a circuit split that had developed wherein four circuits held that "me too" evidence was essentially irrelevant and therefore inadmissible. ${ }^{51}$ The Supreme Court held that the appellate courts must uphold Rule 403 rulings unless the district court has abused its discretion. ${ }^{52}$ Far from creating a clear standard, the Court held "such evidence is neither per se admissible nor per se inadmissible." "53 As explained in the subsequent sections of this Note, courts are now left to determine the admissibility of "me too" evidence on a case-by-case basis.

\section{Application in Lower Courts}

On remand, the United States District Court for the District of Kansas responded to the Supreme Court's Mendelsohn holding by providing factored reasons as to why "me too" evidence should be excluded from evidence. ${ }^{54}$ Since this ruling, the Supreme Court decision has begun to trickle down to the lower courts, which have interpreted the Mendelsohn holding in a variety of ways. Courts have not pushed back on the Mendelsohn ruling, but instead have opted to construct factors and tests similar to the District of Kansas to evaluate the admissibility of "me too" evidence. Courts have accepted that while Mendelsohn may not provide a clear standard of what to do, it is very clear on what not to do-base a decision on a singular factor. ${ }^{55}$

At the federal trial court level, Hayes $v$. Sebelius demonstrates a typical manner in which trial courts have operated with the protection offered by Mendelsohn. ${ }^{56}$ In Hayes a number of factors are identified and each of them are evaluated to determine the probative value of the evidence. Hayes used the following factors: "(1) whether past

\footnotetext{
49. Id. at 1231 (giving "the evidence its maximum reasonable probative force and its minimum reasonable prejudicial value" (notably identical to the proposed min-max test)).

50. Id.

51. Petition for a Writ of Certiorari at 5, Mendelsohn, 552 U.S. 379 (No. 06-1221), 2007 WL 738928 , at *i (noting that "four circuits have held 'me, too' evidence wholly irrelevant").

52. Sprint/United Mgmt. Co. v. Mendelsohn, 552 U.S. 379, 387-88 (2008).

53. Id. at 381 (emphasis in original).

54. Mendelsohn v. Sprint/United Mgmt. Co., 587 F. Supp. 2d 1201, 1217-20 (D. Kan. 2008).

55. Griffin v. Finkbeiner, 689 F.3d 584, 598-600 (6th Cir. 2012).

56. 806 F. Supp. 2 d 141, 144-45 (D.D.C. 2011).
} 
discriminatory or retaliatory behavior is close in time to the events at issue in the case, (2) whether the same decisionmaker was involved, (3) whether the witness and plaintiff were treated in the same manner, and (4) whether the witness and plaintiff were otherwise similarly situated." ${ }^{57}$ It is relevant to note that Hayes still asks each of these questions - it does not base its determination on a singular factor.

At the appellate level, Calobrisi v. Booz Allen Hamilton, Inc. demonstrates an example of a remand performed when "the district court did not individually analyze each piece of other employee evidence. . .."58 Before Mendelsohn, a court at the appellate level may have evaluated the "me too" evidence. But in Calobrisi, the court followed the Mendelsohn approach and remanded the case without weighing the probative and prejudicial factors for the trial court. ${ }^{59}$ The court rearticulated the factors the trial court could use to evaluate the evidence, but ultimately allowed the trial court to be the final gatekeeper of the evidence. ${ }^{60}$ So, after Mendelsohn, courts were left right where they had started - fighting about admission to the trial court.

\section{THE MINIMUM-MAXIMUM TEST}

While not an issue in Mendelsohn, courts use several different tests to determine the probative and prejudicial weight of evidence. Judge Weinstein and Professor Margaret Berger's treatise on evidence describes one such Rule 403 test. ${ }^{61}$ Under the Weinstein/Berger approach, the applicable test for Rule 403 is to "look at the evidence in a light most favorable to its proponent, maximizing its probative value and minimizing its prejudicial effect." ${ }^{\prime 2}$ This is known as the min-max test. ${ }^{63}$ In addition, the Editorial Explanatory Comment of the Federal Rules of Evidence Manual has recognized this test as preferable to tests that place a maximized value on prejudicial impact. ${ }^{64}$ This test is reflective of the liberal nature of Rule 403, which imposes a steep burden to overcome the

\footnotetext{
57. Id. (emphasis added).

58. 660 F. App'x 207, 210 (4th Cir. 2016).

59. Id.

60. Id. at 209-10.

61. JaCK B. Weinstein \& Margaret A. Berger, Weinstein's Evidence Manual $§ 6.02$ (7th ed. 2005).

62. Leah Tabbert, Note, Maximizing the Min-Max Test: A Proposal To Unify the Framework for Rule 403 Decisions, 100 MinN. L. REv. 2217, 2217-18 (2016).

63. Id. at 2217.

64. Stephen A. Saltzburg et al., Federal Rules of Evidence Manual § 403.02[2] (Matthew Bender 11th ed. 2018).
} 
presumption that a court should admit the evidence. ${ }^{65}$ At its core, Rule 403 prevents the extremities of potential jury decisions and protects these decisions from the dangers of prejudice. ${ }^{66}$ The min-max test for determining how probative and prejudicial values should be weighed recognizes the value of jury independence and discretion. ${ }^{67}$ Instead of placing the burden on the judge to filter the evidence for the jury, this interpretation considers the jury capable of forming justified conclusions. ${ }^{68}$

This test is widely used by courts to weigh the probative and prejudicial value of evidence. In fact, it has been implemented in the Second, Fourth, Fifth, Sixth, Seventh, Tenth, and Eleventh Circuits. ${ }^{69}$ Some of these circuits consistently apply this test when considering appeals of admitted evidence. ${ }^{70}$ Other circuits (including the Tenth) have used "the min-max test as a duty of the trial court as well as the appellate court." 71 Because the rule offers a greater chance for admission, the majority of federal circuits have used this test as a method of review at the appellate level to allow trial court discretion. ${ }^{72}$ This Note advocates for the application of this test at the trial court and appellate levels to extend this discretion to the jury. ${ }^{73}$

While typically employed during appellate review, the min-max test is easily operable at the trial court level. Kansas Appellate Courts would still have the ability to review for abuse of discretion if Kansas courts adopted the min-max test. Additionally, applying the min-max test to the trial court avoids a major issue that occurs when only appellate courts apply the test. On one hand, as established, Rule 403 and K.S.A. $§ 60-445$ both have a strong presumption of admission ${ }^{74}$ as both require that the probative value be substantially outweighed by the negative factors. ${ }^{75} \mathrm{On}$ the other, a trial court possesses a significant level of discretion in

\footnotetext{
65. David Crump, On the Uses of Irrelevant Evidence, 34 Hous. L. REV. 1, 3-4 (1997).

66. Tabbert, supra note 62, at 2223-24.

67. See id. at 2223.

68. Id.

69. See Tabbert, supra note 62 , at 2229.

70. Id. at 2230 .

71. Id. at 2231; Deters v. Equifax Credit Info. Servs., Inc., 202 F.3d 1262, 1274 (10th Cir. 2000).

72. Tabbert, supra note 62 , at 2220 .

73. See id. at 2239, 2250 (noting the tensions between Rule 402's exclusion of evidence from the jury while recognizing the right to trial by jury and advocating for amendment to Rule 403 to bind trial and appellate courts to the min-max test).

74. Christopher M. Joseph, Other Misconduct Evidence: Rethinking Kansas Statutes Annotated Section 60-455, 49 U. KAN. L. REV. 145, 190 (2000) (examining the legislative history of K.S.A. § 60445, which stems from Model Rule 55 prior to the creation of the Federal Rules of Evidence).

75. FED. R. EVID. 403; KAN. STAT. ANN. § 60-445 (2005).
} 
determining what evidence is admitted to the record because it possesses a superior position to evaluate the circumstances. ${ }^{76}$ These two presumptions clash when an appellate court (using the min-max test) reviews a trial court's (using traditional test) exclusion of evidence. ${ }^{77}$ The min-max test, by definition, necessarily increases the evaluated probative value of the evidence and decreases its evaluated prejudicial value. ${ }^{78}$ Because the min-max test heightens consideration of the probative value of evidence, it is possible - even probable - that appellate courts will find the maximum potential probative value of evidence is not substantially outweighed by minimized prejudicial impact in a circumstance where the trial court has not adjusted the probative and prejudicial weight of the evidence. ${ }^{79}$ In this case, the presumption to admit the evidence and trial court's discretion come to head. ${ }^{80}$ By adopting the test at both the trial and appellate level, Kansas courts will avoid this issue and be able to allow trial courts discretion while also discouraging unnecessary exclusions. ${ }^{81}$

Critics of the test argue for a narrower reading of Rule 403 and note that the rule is intended to shield a jury from evidence that may cause it to rule in error. ${ }^{82}$ That said, a prerequisite to application of Rule 403 or K.S.A. $§ 60-445$ is proof of relevance. ${ }^{83}$ Because courts are necessarily excluding relevant evidence, many courts have noted that the rule should be used sparingly. ${ }^{84}$ Although applying the min-max test may limit the frequency judges use K.S.A. $\S 60-445$ to exclude evidence, this limitation aligns precisely with the intent of the rule. Regardless, even when the minmax test is used in application to K.S.A. $\S 60-445$, there are litanies of other protections offered by the rest of evidentiary rules that can check a dangerous expansion of evidence. ${ }^{85}$

76. Jack B. Weinstein \& Margaret A. Berger, Weinstein's Federal Evidence § 403.02[2][d] (2d ed. 1997) (citing Sprint/United Mgmt. Co. v. Mendelsohn, 552 U.S. 379, 387-88 (2008)).

77. Tabbert, supra note 62, at 2242-43.

78. Id. at 2217.

79. Id. at 2242 .

80. Id.

81. Id. at 2250 .

82. Id. at 2218 .

83. Fed. R. Evid. 403; Kan. Stat. AnN. § 60-445 (giving the judge discretion to exclude evidence that is otherwise admissible).

84. See United States v. Hogan, 253 F. App'x 889, 896 (11th Cir. 2007); United States v. Morris, 79 F.3d 409, 412 (5th Cir. 1996); State v. Seacat, 366 P.3d 208, 221 (Kan. 2016) ("Kansas law favors the admission of otherwise relevant evidence, and the exclusion of relevant evidence is an extraordinary remedy that should be used sparingly.") (citing State v. Carr, 331 P.3d 544, 683-84 (Kan. 2014)).

85. See, e.g., Kan. Stat. AnN. § 60-447 (2005) (limiting the use of character evidence); Kan. STAT. ANN. § 60-451 (2005) (prohibiting the use of evidence of remedial measures to prove negligence 
This test provides a unique advantage when evaluating the potential impact of evidence - particularly in the employment setting. Rule 403 has been viewed as so broad "the rule could be applied to support almost any result." 86 When determining what is considered prejudicial value, the Federal Rules of Evidence Manual says, "prejudicial evidence is any evidence that affects the trier of fact in a manner not attributable to the permissible probative force of the evidence." ${ }^{87}$ To determine the probative value, a judge must determine how well the evidence supports a material fact and how central that fact is to the overall claim. ${ }^{88}$ A judge should determine whether a particular piece of evidence is relevant, but narrowly construing the role of the judge in excluding evidence is critical to prevent judges from assessing credibility. ${ }^{89}$ Rule 403 necessarily involves a level of discretion when determining the weight of the probative and prejudicial impact. The min-max test creates a much more predictable result by consistently increasing the probative value of the evidence. This predictability can aid parties in the pre-trial process, judges in deliberation, and appeals courts upon question.

\section{KANSAS’S RULE OF PREJUdICIAL INADMISSIBILITY}

Kansas courts have applied K.S.A. $\S 60-445$, using a probativeprejudice evaluation to determine admissibility. ${ }^{90}$ This standard for the Kansas rule is not as clear-cut as Rule 403. Often, courts hold evidence inadmissible when "more prejudicial than probative... pursuant to K.S.A. § 60-445." 91 However, these courts have not consistently applied this standard when weighing the probative and prejudicial values. Each level of Kansas courts have applied the test using different thresholds. Sometimes, a court articulates the standard as allowing exclusion when probative value is substantially outweighed by unfair prejudice. ${ }^{92}$ Other

\footnotetext{
or culpable conduct); FED. R. EVID. 403 advisory committee's note (Each of the Article IV Rules are intended to be "concrete applications [of rules 402 and 403] evolved for particular situations.").

86. Tabbert, supra note 62, at 2233.

87. SALTZBURG ET AL., supra note 64, at $\S 403.02[3]$.

88. See Tabbert, supra note 62, at 2234.

89. Edward J. Imwinkelried, The Meaning of Probative Value and Prejudice in Federal Rule of Evidence 403: Can Rule 403 Be Used to Resurrect the Common Law of Evidence?, 41 VAND. L. REV. 879, 887 (1988).

90. Ratterree v. Bartlett, 707 P.2d 1063, 1069 (Kan. 1985).

91. Id. See also State v. Trotter, 127 P.3d 972, 980 (Kan. 2006).

92. See State v. Lowrance, 312 P.3d 328, 341 (Kan. 2013) (misstating the rule in State v. Reid, 186 P.3d 713, 721 (Kan. 2008)); State v. Marks, 298 P.3d 1102, 1113 (Kan. 2013); State v. Mitchell, 179 P.3d 394, 397 (Kan. 2008); State v. Davis, 515 P.2d 802, 805 (Kan. 1973); State v. Rodman, 383 P.3d 187, 194 (Kan. Ct. App. 2016).
} 
times, courts require the prejudice to outweigh the probative valueremoving the substantial requirement. ${ }^{93}$ In Ratterree v. Bartlett, the Kansas Supreme Court effectively wrote prejudicial value into the rule holding, "the trial court correctly ruled the evidence of the smell of alcohol on Hernandez' breath would be more prejudicial than probative and correctly excluded the evidence." 94 However, likely because of the varied text of K.S.A. $\S 60-445$, the application has been inconsistent.

Kansas does not operate under the Federal Rules of Evidence, but courts often use the Rules as persuasive authority when the Kansas evidentiary rules create a question of interpretation. ${ }^{95}$ As noted above, K.S.A. § 60-445 creates one such gap - clearly demonstrated by the inconsistent application of K.S.A. $\S 60-445 .{ }^{96}$ There are clear and significant differences between Rule 403 and K.S.A. $\S 60-445 .{ }^{97}$ First, the two rules have significant textual differences. Rule 403 provides a clear standard to evaluate the probative and prejudicial value of evidence. Rule 403 says, "The court may exclude relevant evidence if its probative value is substantially outweighed by a danger of one or more of the following: unfair prejudice, confusing the issues, misleading the jury, undue delay, wasting time, or needlessly presenting cumulative evidence." 98

K.S.A. $\S 60-445$, on the other hand, reads:

Except as in this article otherwise provided, the judge may in his or her discretion exclude evidence if he or she finds that its probative value is substantially outweighed by the risk that its admission will unfairly and harmfully surprise a party who has not had reasonable opportunity to anticipate that such evidence would be offered. ${ }^{99}$

At first glance, these two rules contain very similar wording. Both the Kansas rule and Rule 403 require a court to weigh the probative value of admitting evidence. ${ }^{100}$ Additionally, both include the phrase "substantially outweigh." 101 It is important to note, though, that the

\footnotetext{
93. See State v. Decker, 202 P.3d 669, 673 (Kan. 2009); State v. Wells, 221 P.3d 561, 568 (Kan. 2009); Reid, 186 P.3d at 721; State v. Trotter, 127 P.3d 972, 980 (Kan. 2006); State v. Herzog, 2001 Kan. App. Unpub. LEXIS 551, at*7-8 (Kan. Ct. App. Sept. 7, 2001).

94. Ratterree, 707 P.2d at 1069 (citing K.S.A. § 60-445).

95. See, e.g., Reid, 186 P.3d at 722 (recognizing and comparing the Federal Rule to its "Kansas counterpart"); Smart v. BNSF Ry. Co., 369 P.3d 966, 973 (Kan. Ct. App. 2016) (finding that the federal rules should be used as persuasive authority to interpret similar rules).

96. See cases cited supra notes 92-93.

97. See FED. R. EVID. 403; KAN. STAT. ANN. § 60-445.

98. FED. R. EVID. 403.

99. KAN. STAT. ANN. § 60-445.

100. See FED. R. Evid. 403; KAN. StAT. ANN. § 60-445.

101. Id.
} 
Kansas rule does not expressly require courts to evaluate the "prejudicial" damage that evidence may create. ${ }^{102}$ The Kansas rule was written to prevent evidence that would "unfairly and harmfully surprise a party." 103 This demonstrates a clear textual difference between the two. In fact, the committee notes for the Federal Rules of Evidence contrast the inclusion of "surprise" in the Kansas statute with the purposeful exclusion within the federal rules. ${ }^{104}$ Based on the text of the Kansas statute standing alone, the standard for admitting evidence does not require the balancing of prejudicial impact outside a potential for surprise.

However, as noted above, courts have generally concluded that prejudicial value should be weighed in determining whether the evidence is admitted under K.S.A. $§ 60-445 .{ }^{105}$ More conclusively, in State v. Lee, the Kansas Supreme Court decided that the progression of common law (specifically the Ratterree v. Bartlett decision) effectively placed "unfair prejudice" in K.S.A. § 60-445, making the statute comparable to Rule 403 and other equivalent state statutes. ${ }^{106}$ The Kansas Supreme Court adopted the reasoning of the federal case Old Chief v. United States and found "no distinction between Federal Rule 403 and K.S.A. [ $\$$ ] 60-445 based on the absence from $\S 60-445$ of the phrase "unfair prejudice."'107

\section{ANALYSIS}

The Kansas Supreme Court should require the min-max test to be applied at the trial and appellate levels when evaluating the admission of evidence under K.S.A. $\S 60-445$. Kansas courts have applied its prejudicial inadmissibility in numerous ways - none of which are textually true to the written rule. State v. Lee adopted the reasoning of Old Chief and incorporated prejudice into K.S.A. $\S 60-445$, but was silent on how to properly weigh the prejudicial impact and probative value. ${ }^{108}$ If courts apply the min-max test, the probative value of "me too" evidence would be considered at its maximum value and its prejudicial impacts minimized, increasing the likelihood of its admission.

Kansas courts' application of the test in "me too" cases is uniquely important for several reasons. The Kansas Supreme Court has a direct interest in the efficiency and effectiveness of trials. By consistently

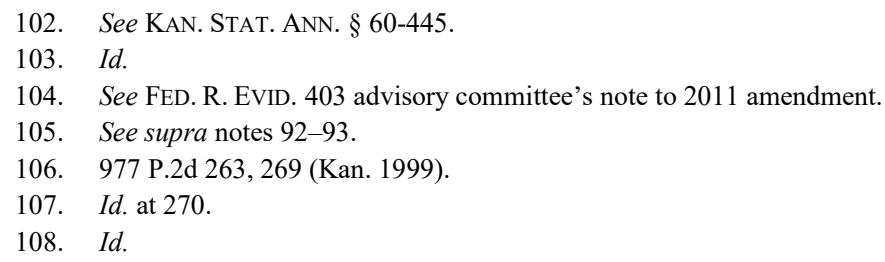


applying the min-max test, a court can make the admissibility more predictable while also ensuring the proper evaluation of relevant evidence. More significantly, courts that apply the min-max test will compensate for the systemic disadvantage that employees face in cases of employment discrimination. While employees face an uphill battle in discrimination and harassment claims, the min-max test will increase the likelihood that courts will admit evidence that is critical to their case for jury consideration. Employees in "me too" scenarios face burdens to getting cases to trial, establishing concrete evidence, finding testimony identical to their own harassment, and are often contractually forced to isolate personal claims. Each of these barriers hampers the potential for victims of sexual harassment to be compensated for workplace conduct. While this inclusion of evidence could increase the potential that courts could admit false testimony, testimony can be independently attacked for credibility and evaluated by the jury.

\section{A. Trial Effectiveness and Efficiency}

In International Brotherhood of Teamsters v. United States, the Supreme Court unanimously said, "individuals who testified about their personal experiences with the company brought the cold numbers convincingly to life." ${ }^{109}$ It is almost undeniable that personal accounts of sexual harassment and discrimination have more practical significance than numbers, statistics, or even recited facts of similar experiences. Allowing testimony into trial will encourage a more full and transparent view of the issue at hand. If the Kavanaugh hearing demonstrates any positive social implications, it is the importance of engaging in face-toface discussion. Hearing from a real person is significantly different from second-hand information or statistics.

This is not to say that every witness will be believed. An important part about this change in evidentiary rules is that it allows the information to reach the decision maker-including evidence provided by the defendant. Allowing both sides to develop arguments fully will ensure the jury will be able to make a decision that is based on a full presentation of information.

Not only does the testimony improve the evidentiary quality of the trial, it also has the ability to improve judicial efficiency. Using the evenly balanced Rule 403 standard of review, courts are forced to accurately predict and assess the actual probative and prejudicial value of the

109. 431 U.S. 324,339 (1977). 
evidence in question. Because this frequently renders close decisions, courts have chosen to deny motions in limine and hold an evidentiary hearing later. ${ }^{110}$ Unfortunately, this is not effective for any of the parties involved. When attempting to settle or prepare for trial, the parties are unaware of whether extremely relevant evidence will make it into the courtroom. ${ }^{111}$ This also can add additional time to litigation, as the parties have to debate what gets to come into trial. Allowing the jury to hear evidence from both sides at trial would help both parties accurately predict and assess their costs for pursuing litigation.

\section{B. Courts' Application of the Min-Max Test Addresses Procedural Disadvantages Faced by Employees}

If Kansas courts adopt the broader min-max test, it could have significant impacts on the ability of employees to seek action against employers in harassment and discrimination suits. This is not simply to address a social issue. By adopting this broader interpretation and test, Kansas courts can address procedural disadvantages such as pretrial barriers, access to legal remedies, lack of direct evidence, and additional barriers faced by people with intersecting identities. Plaintiffs in employment discrimination cases have comparatively lower rates of relief than other cases. ${ }^{112}$ It is not a question of whether harassment or discrimination is occurring - as addressed above, we know that is true. ${ }^{113}$ The problem is that we often only talk about sexual harassment and discrimination as isolated actions against the individual. ${ }^{114}$ This is not a fair assessment of what has occurred. Sexual harassment and discrimination in the workplace inherently involve the power dynamic created by employment. Individuals that occupy positions of power often have different levels of employment security as well, decreasing the chance a company will take action. ${ }^{115}$ As we have seen from the "Me Too"

110. See, e.g., Miller v. Love's Travel Stops \& Country Stores, Inc., No. CIV-06-1008-D, 2008 WL 2079961, at *2 (W.D. Okla. May 9, 2008).

111. See, e.g., Jones v. UPS, No. 06-2143-KHV, 2008 U.S. Dist. LEXIS 24772 (D. Kan. Mar. 27, 2008).

112. Michael Selmi, Why Are Employment Discrimination Cases So Hard To Win?, 61 LA. L. REV. 555, 557-61 (2001).

113. See supra notes 8-9 and accompanying text.

114. See Vicki Schultz, Reconceptualizing Sexual Harassment, Again, 128 YAlE L.J. F. 27, 33-34 (2018) (challenging the traditional "predatory sexuality" theory of sexual harassment and arguing instead that sexual harassment is more about power dynamics, masculinity, and sex-based hostility).

115. See generally Stewart J. Schwab \& Randall S. Thomas, An Empirical Analysis of CEO Employment Contracts: What Do Top Executives Bargain For?, 63 WASH. \& LEE L. REv. 231, 233 
era, when men occupy positions of power, there is a significant risk that the women beneath them are defenseless. It is critical to look at the larger issue of how employees are situated in relation to employers and the structural barriers that must be overcome to address these issues.

To illustrate these issues, consider a hypothetical involving a lowlevel senior Black woman terminated after enduring weeks of on-the-job harassment. For purposes of this hypothetical, assume that the direct male supervisor made blatantly sexist and racist remarks and openly discussed the burden that older employees place on business operations amongst other high-level male supervisors. There is no written or recorded evidence of any of the supervisor's conduct, but multiple lower-level employees have also witnessed and experienced either sexist, racist, or ageist harassment. Our employee previously filed a complaint with HR and now wants to pursue legal action. This fairly typical example of employment discrimination will demonstrate some key issues faced by victims of workplace harassment and the importance of applying the minmax test in cases of "me too" testimony.

The first problem an employee faces that makes this change in rules especially important is the barriers she must overcome to reach trial. The California Department of Fair Employment and Housing (the "Department") acts as a magnified illustration of this issue. In 2017, the Department investigated 6,160 complaints and filed only thirty-five lawsuits in court. ${ }^{116}$ In many cases, employees that are potential witnesses may provide relevant probative evidence that remains unreported solely because of corporate attempts to suppress accusations. ${ }^{117}$ Employers, especially corporate employers, possess a large information imbalance. Besides their access to records and office information, they also frequently control the manner and process of reporting. In our hypothetical, the employer would have regulated the manner in which the employee filed her HR complaint, had access to all internal communications, and during litigation would be able to view and compare other complaints issued by other employees. This information disparity places victims of sexual

(2006) (noting that CEOs frequently bargain for and obtain some measure of job security, avoiding the general principle of at-will employment).

116. DeP'T FAIR EMP. \& Housing, ST. OF CAL., 2017 AnN. ReP. 7 (2017), https://www.dfeh.ca.gov/wp-content/uploads/sites/32/2018/08/DFEH-AnnualReport-2017.pdf (Contextually, the DFEH received 24,779 complaints in 2017).

117. See Susan J. Fowler, Reflecting On One Very, Very Strange Year At Uber, SuSAN J. FowLER BLOG (Feb. 19, 2017), https://www.susanjfowler.com/blog/2017/2/19/reflecting-on-one-verystrange-year-at-uber [https://perma.cc/79GN-XZBW] (relating the author's experience while working at Uber where HR repeatedly dismissed female employees' complaints of sexual harassment against the same manager as "his first offense."). 
harassment at a unique disadvantage that can deter or dissuade an employee from pursuing a claim.

Additionally, employers hold the inherent advantage of economic power. Employers typically classify low-level employees at-will, placing their economic liberties at risk. ${ }^{118}$ Because other employees may fear the economic ramifications of testifying against the employer, evidence is significantly more difficult for a plaintiff to obtain. While some retaliation protections exist, ${ }^{119}$ reporting an employer's misconduct is especially difficult for both the plaintiff and the corroborating witness as "both exit and voice are costly and constrained for workers." 120 Because the employer controls day-to-day operations as well as long-term employment, the risk of vocalizing the mistreatment is high. In our hypothetical, our plaintiff may have endured discrimination in fear of termination, and now must convince other employees to provide testimony (for little-to-no personal gain) and risk their own economic stability. Our now-unemployed plaintiff must exhaust personal resources including time and potentially high financial expenses to compete with the multitude of corporate resources while also encouraging other employees to risk termination by providing testimony. Once other employees come forward to corroborate the harassment experience of the plaintiff, it only seems fitting that the court provide a lenient test to determine whether evidence can even make it to the jury.

Second, in many cases, individuals experience contractual issues that make their access to legal remedies more difficult. In larger companies, trends of sexual harassment and discrimination may root deep in policy, often found in clauses that forbid employees in engaging in class action lawsuits against the company. ${ }^{121}$ The significance of this will only continue to grow. The Supreme Court recently held in Epic Systems Corporation $v$. Lewis that these waivers of class action rights were

118. Richard A. Bales, Explaining the Spread of At-Will Employment as an Interjurisdictional Race to the Bottom of Employment Standards, 75 TENN. L. REV. 453, 453, 460-67 (2008) (defining "at-will" employment and providing a brief history of the doctrine); The At-Will Presumption and Exceptions to the Rule, NAT'L CONF. OF ST. LEGISLATURES, http://www.ncsl.org/research/labor-andemployment/at-will-employment-overview.aspx [https://perma.cc/SS6G-CPAW] (last visited Apr. 1, 2019).

119. 42 U.S.C. $\S 2000 \mathrm{e}-3$ (2012).

120. Cynthia Estlund, Truth, Lies, and Power at Work, 101 MinN. L. REv. HEADNOTES 349, 360 (2017).

121. See, e.g., Nitasha Tiku, Big Tech Eyes Supreme Court's Employee-Arbitration Case, WIRED (Oct. 2, 2017, 7:00AM), https://www.wired.com/story/big-tech-eyes-supreme-courts-employeearbitration-case/ [https://perma.cc/B49L-PK3G] (discussing Uber's mandatory-arbitration clause and Google's class waiver provision in employment contracts). 
acceptable under the National Labor Relations Act. ${ }^{122}$ In Justice Ginsburg's dissent she argues, "concerted legal actions have played a critical role in enforcing prohibitions against workplace discrimination based on race, sex, and other protected characteristics." 123 This ruling allows companies to shift women away from the courtroom. As the "Me Too" era has demonstrated, women feel empowered to come forward with other women. Thus, while our hypothetical employee may have been comfortable joining a class action against the employer, the Epic Systems holding further isolates plaintiffs and removes their strength in numbers. The min-max test acts to ameliorate negative impact of the no-class-action ruling and allows plaintiffs to retain a significant litigation tool.

The isolation of harassment claims also creates a larger social issue. When employees are not able to come together in class action suits, employers may never address company-wide issues. Empirical research demonstrates that "entities necessarily shape the context in which individuals act and interact and that they accordingly drive behavior" of the seemingly isolated individuals within an organization. ${ }^{124}$ When courts conceptualize suits as isolated individualized occurrences, women are forced to win a war against discrimination and harassment using a strategy of death by a thousand cuts. ${ }^{125}$ Even if successful, our isolated hypothetical lawsuit will not likely change the workplace culture, nor will it necessarily embolden other people to pursue isolated claims. However, if women are consistently able to testify for other women about their experiences in the workplace, the justice system may be able to compensate for this loss of potential recourse. Having a test that consistently allows "me too" evidence into trial is important to ensure women know that providing their name and getting involved in the process is worth the risk.

This poses an interesting predicament for those that argue men are being subjected to excessive disciplinary action. Rank-and-file employees often do not benefit from the same power dynamic as high-level employers and are instead vulnerable to systemic disciplinary scapegoating. ${ }^{126}$ In a work culture of HR trainings, strategic procedural changes, conveniently-

\footnotetext{
122. 138 S. Ct. 1612,1632 (2018).

123. Id. at 1648 .

124. Tristin K. Green, The Future of Systemic Disparate Treatment Law, 32 BERKELEY J. EMP. \& LAB. L. 395, 449 (2011), https://scholarship.law.berkeley.edu/cgi/viewcontent.cgi?article=1440\& context=bjell [https://perma.cc/XY6V-JZFC] (describing the implications of conceptualizing discrimination as an individualized problem).

125. Id. at 448-49.

126. Rachel Arnow-Richman, Of Power and Process: Handling Harassers in an At-Will World, 128 YALE L.J. F. 85, 91 (2018).
} 
timed disciplinary actions, lower-level employees are more likely to be subjected to unfair discipline in the process of shielding higher-level employees from suits. ${ }^{127}$ In contrast to rank employees, higher-level employees frequently bargain for protection from termination and cannot be fired unless the harassment or discrimination is classified as "extreme" - a designation implicated by the potential for multiple violations. ${ }^{128}$ If the unjust discipline of less-protected parties indeed concerns a court, allowing additional testimony would force solutions to address top-down solutions to systemic problems as opposed to treating the symptoms of the organization. In our hypothetical, it is very realistic that the sexist, racist, and ageist discussions among supervisors may be indicative of a higher-level issue. Applying the min-max test in cases of employment discrimination would account for this corporate dynamic and recognize the potential probative value "me too" evidence can provide when assessing cases of sexual harassment and discrimination.

Third, when discussing issues of employment discrimination, the Supreme Court has not hesitated to recognize a plaintiff's lack of access to direct evidence. ${ }^{129}$ In cases of harassment and discrimination, cases often come down to circumstantial evidence. Even if the harassment is repetitious and apparent, cases involving workplace misconduct often involve verbal exchanges or personal interactions. These do not usually solidify into concrete evidence-leaving employees without evidence to support their case. ${ }^{130}$ This is certainly true in our hypothetical where our employee has experienced clear harassment but has no concrete evidence to present to a court. This has only become truer over time as employers are increasingly aware of the importance of not leaving concrete evidence of discrimination. ${ }^{131}$ Our hypothetical employee would be extremely fortunate (for lack of better terms) if her employer were to send a harassing

\footnotetext{
127. Id. at 91-92.

128. Id.

129. See Price Waterhouse v. Hopkins, 490 U.S. 228, 271 (1989) (O’Connor, J., concurring) (“As should be apparent, the entire purpose of the McDonnell Douglas prima facie case is to compensate for the fact that direct evidence of intentional discrimination is hard to come by.").

130. See Jessica A. Clarke, Explicit Bias, 113 Nw. U. L. Rev. 505, 543-46 (2018) (discussing the inferential evidence that remains critical to plaintiffs' discrimination claims); Joseph A. Seiner, The Discrimination Presumption, 94 NotRE DAME L. REV. 1116, 1125-26 (2019) (noting employees' disadvantages in gathering evidence of intentional discrimination because of employer control over relevant documentation and reluctance to share personal information).

131. See Devah Pager \& Lincoln Quillian, Walking the Walk? What Employers Say Versus What They Do, 70 AM. Soc. REv. 355, 360-61 (2005) (distinguishing employers' open and conscious recognition of inappropriate workplace discrimination with proxy and/or implicit discrimination); Selmi, supra note 112, at 576 (2001) (noting the compounded impact of information asymmetry; employers have a vested interest in concealing any concrete or direct evidence of employment discrimination).
} 
email or text. Unfortunately, "me too" evidence is often the only type of evidence that is available to develop a credible case-even in cases involving company-wide harassment or discrimination. ${ }^{132}$ When applying the min-max test, the maximized weight of probative value would be reflective of this fact and remedy the disparity in evidence possession.

Historically, some have argued the prejudicial impact of "me too" testimony is significantly greater than the probative value of the evidence. ${ }^{133}$ Because the testimony inevitably combines elements of emotion and circumstance, opponents assert that defendants often face disproportionate consequences. ${ }^{134}$ However, an important consideration is whether the prejudice that occurs is unfair. Because cases of workplace harassment and discrimination usually require broader workplace inquiries, multiple instances of similar conduct may suggest an intent, motive, or knowledge of discrimination at the institutional level. ${ }^{135}$ So while it may be true that circumstantial evidence is prejudicial, this does not mean it is unfairly so.

Furthermore, even assuming a clear balancing test for admission, the estimation of actual (as opposed to potential) probative value of circumstantial evidence can prove problematic. Weighing the evidence requires on-the-spot balancing of probative value and prejudicial impact and each piece of evidence may come at different stages of a suit. ${ }^{136}$ In Old Chief v. United States (as noted above, Kansas adopted this reasoning in State v. Lee), the Supreme Court articulates the scope of considerations to be considered when calculating probative and prejudicial values. ${ }^{137}$ When determining admission, a court should consider not only the value of the independent evidence, but also the role the evidence plays in conjunction with other pieces of evidence in the record. ${ }^{138}$ If K.S.A. $\S 60$ 445 were applied in either manner currently used by the State's courts, this

132. Emma Pelkey, The "Not Me Too" Evidence Doctrine in Employment Law: Courts" Disparate Treatment of "Me Too" Versus "Not Me Too" Evidence in Employment Discrimination Cases, 92 OR. L. REv. 545, 566-570 (2013) (noting that employees need me-too evidence because of the employer-employee information disparity, lack of direct evidence, and the McDonnell Douglas employer bias).

133. Charles C. Warner, Motions in Limine in Employment Discrimination Litigation, 29 U. MEM. L. REV. 823, 828 n.22 (1999) (listing the circuits that have chosen to exclude "me too" evidence under the rationale of prejudice).

134. Id.

135. Nicholas C. Soltman, What about "Me (Too)"? The Case for Admitting Evidence of Discrimination Against Nonparties, 76 U. CHI. L. REV. 1875, 1905 (2009).

136. See Steven Alan Childress \& Martha S. Davies, Fed. Standards OF ReV. $\$ 4.02$ (4th ed. 2018).

137. 519 U.S. 172, 184 (1997).

138. Id. 
would create a unique problem in cases involving "me too" evidence. As noted in Mendelsohn, the value of "me too" testimony, is not inherent within the evidence, but instead requires a context-specific inquiry. ${ }^{139}$ The Court in Old Chief says that courts should incorporate the scarcity of evidence into a calculation of probative value. ${ }^{140}$ Because employment discrimination and harassment cases often have little evidence outside of circumstantial "me too" testimony, a judge would be forced to either functionally weigh the evidence independently, or weigh testimony against potential, currently unoffered evidence.

Fourth, employees with claims that involve multiple (intersecting) forms of discrimination face additional barriers in developing evidentiary basis that has significant implications for case viability. An interdisciplinary statistical study of workplace discrimination claims filed by those with overlapping ascriptive characteristics found that "those who assert two or more types of discrimination fare worse than do those whose cases [do not]." ${ }^{141}$ Because individuals with intersecting identities (such as Black women, senior women, or our hypothetical senior Black woman) may not be able to find other employees with identical experiences, these employees require the testimony of a larger number of employees that experienced similar, but not the same, discrimination or harassment. ${ }^{142}$ For example, our hypothetical senior woman of color may require three separate testimonies if there is not an employee who is also a senior woman of color who also experienced discrimination. In these cases, the isolated probative value of an individual's testimony is unquestionably somewhat lower than the testimony of a non-plaintiff witness who experienced discrimination along one axis of identity. If courts view the testimony of these individual witnesses through an unadjusted test, it is possible the prejudicial impact of these individuals' testimony will outweigh its probative value. Mendelsohn requires courts to analyze the similarity in experience between the testimony of a third-party when determining probative value while also evaluating the independent

\footnotetext{
139. Sprint/United Mgmt. Co. v. Mendelsohn, 552 U.S. 379, 387-88 (2008).

140. Old Chief, 519 U.S. at 184.

141. Rachel Kahn Best et al., Multiple Disadvantages: An Empirical Test of Intersectionality Theory in EEO Litigation, 45 LAW \& SoC'Y REV. 991, 1019 (2011). See also, Emma Reece Denny, Mo' Claims Mo' Problems: How Courts Ignore Multiple Claimants in Employment Discrimination Litigation, 30 LAW \& INEQ. 339, 355 (2012) (citing, among other statistics, that 7.5\% of multipleclaim plaintiffs make it past the summary judgment stage as opposed to $30.3 \%$ of single-claim plaintiffs.).

142. Minna J. Kotkin, Diversity and Discrimination: A Look at Complex Bias, 50 WM. \& MARY L. REV. 1439, 1491 (2009).
} 
prejudicial impact of that testimony. ${ }^{143}$ In this hypothetical, each provides only a third of the facts necessary for the plaintiff to establish her case, but at the same time, each independently represents an independent case of discriminatory action by the defendant.

Historically, employers have covertly used intersection of identities to isolate and discriminate. ${ }^{144}$ Kimberle Crenshaw identifies one such example. In Degraffenreid v. GM Assembly Division, a company which refused to hire Black women until 1964, conveniently conducted a series of "last hired-first fired" seniority-based lay-offs. ${ }^{145}$ When analyzing the result of this lay-off, white women and Black men both retained their employment providing statistical data demonstrating a lack of racial and gender discrimination. ${ }^{146}$ Because of this, the U.S. District Court for the Eastern District of Missouri granted summary judgment in the case and determined there was no evidence of racial or gender discrimination. ${ }^{147}$ While the outcome in today's society would likely not be as extreme as Crenshaw's example, it is important to recognize the significant impact these decisions can have. For many employees, economic dependence on a discriminatory employer is day-to-day reality. Giving juries access to information is critical to allowing public citizens to check these social imbalances.

While it may be possible to establish a pattern of discrimination, this may not always be the case, as shown by a recent Missouri Supreme Court decision involving a similar issue. In Cox v. Kansas City Chiefs Football $C l u b$, an employer moved to exclude evidence of seventeen non-similarly situated former employees whom Mr. Cox might call to testify. ${ }^{148}$ The trial court excluded the evidence because the plaintiff had not alleged a pattern-or-practice of discrimination and the testifying employees were each positioned differently than Cox in relation to the employer. ${ }^{149}$ However, on appeal, the Missouri Supreme Court held that each instance of "me too" testimony should be subject to an individualized balancing of probativeness and prejudice and should not be rejected in a blanket

\footnotetext{
143. Mendelsohn, 552 U.S. at 387-88.

144. See generally Kimberle Crenshaw, Demarginalizing the Intersection of Race and Sex: A Black Feminist Critique of Antidiscrimination Doctrine, Feminist Theory and Antiracist Politics, 1989 U. CHI. Legal F. 139, 145 (1989).

145. Id. at 141 (citing Degraffenreid v. GM Assembly Div., 413 F. Supp. 142, 143 (E.D. Mo. 1976)).

146. Id. at $142-43$.

147. Id. at 141 .

148. Cox v. Kan. City Chiefs Football Club, Inc., 473 S.W.3d 107, 113 (Mo. 2015).

149. Cox v. Kan. City Chiefs Football Club, Inc., No. WD76616, 2014 Mo. App. LEXIS 840, at *21-22 (Ct. App. Aug. 5, 2014).
} 
ruling. ${ }^{150}$ In weighing the individual instances of "me too" evidence, the Court held that legal relevance must be determined by the presence of logical relevance. ${ }^{151}$ Logical relevance is not determined by defined requirements, but rather a case-by-case evaluation as " $[t]$ here is no one set of agreed-upon factors, and no one factor is dispositive." 152 Therefore, when determining whether "me too" evidence should be included, a court must look at similarities and assess the probative value of evidence and not simply assess the distinguishing features of testimony.

This reasoning is particularly relevant when looking at how Kansas courts should determine admission of "me too" evidence. Functionally, the Cox decision minimized the strict scrutinizing of testimonial variance and focused the consideration on whether or not the individualized testimony offers isolated logical similarities. In the same way, minimizing the prejudicial value of testimony would prevent a court from emphasizing distinguishable variances, while maximizing probative value would instead shift the discussion to isolated similarities.

Each of the independent barriers poses a unique problem for those who experience sexual harassment. Getting a claim to the courtroom requires plaintiffs to overwhelm a litany of obstacles that magnify the risk of speaking out against sexual harassment. When a court has determined that evidence has met the burden of relevance, a test that errs on the side of magnifying potential probative value encourages plaintiffs to attempt to surmount these obstacles in scenarios of sexual harassment and discrimination.

\section{CONCLUSION}

Society's perception and handling of sexual harassment and discrimination claims has changed drastically over the last three decades. As the \#MeToo movement indicates, though, sexual harassment is an extremely prevalent problem that employers are failing to address properly. As the private sector continues to adjust to these changes, it is important the legal system recognizes and adapts to the needs of disadvantaged populations. Independently, Kansas's evidentiary law requires a clear interpretation of K.S.A. $\S 60-445$. Courts have the ability to encourage effective and efficient trials that flush out systemic discrimination and hidden harassment. If Kansas courts require the minimized prejudicial value of "me too" evidence to substantially

150. Cox, 473 S.W.3d, at 124-25.

151. Id.

152. Id. at 122 . 
outweigh the maximized probative value, the voices of the \#MeToo movement will have the opportunity to make it into a courtroom. Kansas can only expect true justice if it allows these testimonies to be heard. 